\title{
Diversity, enrichment, and genomic potential of anaerobic methane- and ammonium-oxidizing microorganisms from a brewery wastewater treatment plant
}

\author{
Karin Stultiens ${ }^{1} \cdot$ Maartje A.H.J. van Kessel ${ }^{1,2}$. Jeroen Frank ${ }^{1} \cdot$ Peter Fischer ${ }^{1,2,3} \cdot$ Chris Pelzer $^{1} \cdot$ Theo A. van Alen ${ }^{1}$. \\ Boran Kartal $^{1,4} \cdot$ Huub J.M. Op den Camp ${ }^{1}$ (D) Mike S.M. Jetten ${ }^{1,2}$
}

Received: 4 May 2020 / Revised: 11 June 2020 / Accepted: 16 June 2020 / Published online: 30 June 2020

(C) The Author(s) 2020

\begin{abstract}
Anaerobic wastewater treatment offers several advantages; however, the effluent of anaerobic digesters still contains high levels of ammonium and dissolved methane that need to be removed before these effluents can be discharged to surface waters. The simultaneous anaerobic removal of methane and ammonium by denitrifying ( $\mathrm{N}$-damo) methanotrophs in combination with anaerobic ammonium-oxidizing (anammox) bacteria could be a potential solution to this challenge. After a molecular survey of a wastewater plant treating brewery effluent, indicating the presence of both $\mathrm{N}$-damo and anammox bacteria, we started an anaerobic bioreactor with a continuous supply of methane, ammonium, and nitrite to enrich these anaerobic microorganisms. After 14 months of operation, a stable enrichment culture containing two types of 'Candidatus Methylomirabilis oxyfera' bacteria and two strains of ' $\mathrm{Ca}$. Brocadia'-like anammox bacteria was achieved. In this community, anammox bacteria converted $80 \%$ of the nitrite with ammonium, while ' $\mathrm{Ca}$. Methylomirabilis' contributed to $20 \%$ of the nitrite consumption. The analysis of metagenomic 16S rRNA reads and fluorescence in situ hybridization (FISH) correlated well and showed that, after 14 months, 'Ca. Methylomirabilis' and anammox bacteria constituted approximately 30 and $20 \%$ of the total microbial community. In addition, a substantial part (10\%) of the community consisted of Phycisphaera-related planctomycetes. Assembly and binning of the metagenomic sequences resulted in high-quality draft genome of two ' $\mathrm{Ca}$. Methylomirabilis' species containing the marker genes pmoCAB, хохF, and nirS and putative $\mathrm{NO}$ dismutase genes. The anammox draft genomes most closely related to ' $\mathrm{Ca}$. Brocadia fulgida' included the marker genes $h z s A B C$, hao, and $h d h$. Whole-reactor and batch anaerobic activity measurements with methane, ammonium, nitrite, and nitrate revealed an average anaerobic methane oxidation rate of $0.12 \mathrm{mmol} \mathrm{h}^{-1} \mathrm{~L}^{-1}$ and ammonium oxidation rate of $0.5 \mathrm{mmol} \mathrm{h}^{-1} \mathrm{~L}^{-1}$. Together, this study describes the enrichment and draft genomes of anaerobic methanotrophs from a brewery wastewater treatment plant, where these organisms together with anammox bacteria can contribute significantly to the removal of methane and ammonium in a more sustainable way.
\end{abstract}

\section{Key points}

- An enrichment culture containing both N-damo and anammox bacteria was obtained.

- Simultaneous consumption of ammonia, nitrite, and methane under anoxic conditions.

- In-depth metagenomic biodiversity analysis of inoculum and enrichment culture.

Electronic supplementary material The online version of this article (https://doi.org/10.1007/s00253-020-10748-z) contains supplementary material, which is available to authorized users.

Huub J.M. Op den Camp

h.opdencamp@science.ru.nl

1 Department of Microbiology, IWWR, Radboud University Nijmegen, Nijmegen, The Netherlands
2 Soehngen Institute of Anaerobic Microbiology, Nijmegen, The Netherlands

3 Present address: Laboratory of Microbiology, Wageningen University \& Research, Wageningen, The Netherlands

4 MPI Bremen, Bremen, Germany 
Keywords Anaerobic oxidation of methane . ' $C a$. Methylomirabilis' bacteria · Anammox - 'Ca. Brocadia' · Nitrite . Metagenome · Hydrazine synthase · pmoA · ' $\mathrm{Ca}$. Methanoperedens nitroreducens'

\section{Introduction}

Anaerobic treatment systems offer many advantages such as biogas production in the form of methane and low sludge production. However, the effluents of anaerobic treatment systems still contain dissolved methane and ammonium that need to be removed. While there are several processes that can be used to remove ammonium from the anaerobic effluents, currently there are no established biological methods to remove dissolved methane, resulting in the release of this potent greenhouse gas into the atmosphere (van Kessel et al. 2018; Xie et al. 2018; Liu et al. 2019; Cogert et al. 2019; Fan et al. 2020). For a long time, it was believed that conversion of methane and ammonium required oxygen (reviewed by in't Zandt et al. 2018). However, in recent years, microbial processes consuming ammonium and methane at the expense of nitrate and/or nitrite have been identified (Strous et al. 1999a; Raghoebarsing et al. 2006; Haroon et al. 2013). The anaerobic ammonium oxidation (anammox) process is performed by bacteria of the Brocadiales which use nitrite or nitric oxide as their terminal electron acceptor (Strous et al. 1999a; Hu et al. 2019). Combined with partial nitrification, this process is applied in many full scale municipal and industrial wastewater treatment plants, and has shown to be sustainable system for nitrogen removal (Kartal et al. 2010; Lackner et al. 2014; Hauck et al. 2016). Nitrate- or nitrite-dependent anaerobic methane oxidation (N-damo) by a consortium of methanotrophic bacteria and archaea was first described in 2006 (Raghoebarsing et al. 2006). The N-damo bacteria, named 'Candidatus Methylomirabilis,' were shown to prefer nitrite as an electron acceptor for methane oxidation, while the N-damo ANME-2d clade archaea seem to use nitrate (Ettwig et al. 2008; Ettwig et al. 2010; Haroon et al. 2013). These archaea, belonging to the genus 'Candidatus Methanoperedens,' oxidize methane via reverse methanogenesis to carbon dioxide while reducing nitrate via nitrite to ammonium (Haroon et al. 2013; Arshad et al. 2015; Ettwig et al. 2016; Vaksmaa et al. 2017a; Gambelli et al. 2018). Because of this production of both nitrite and ammonium, the ' $C a$. Methanoperedens' archaea are very useful partners for both ' $\mathrm{Ca}$. Methylomirabilis' and anammox bacteria (Haroon et al. 2013; Shen et al. 2014; Meng et al. 2016; Arshad et al. 2017; Xu et al. 2017; Fu et al. 2019; Nie et al. $2019,2020)$. This is supported by studies showing these anaerobic methane- and ammonium-oxidizing microorganisms living together in oxygen-limited ecosystems (reviewed in Welte et al. 2016). In these ecosystems, the organisms may also have to compete with each other under substrate limitation (Luesken et al. 2011a; Winkler et al. 2015; Arshad et al. 2017;
Guerrero-Cruz et al. 2019). ' $\mathrm{Ca}$. Methylomirabilis' and ' $\mathrm{Ca}$. Methanoperedens' both utilize methane, while ' $\mathrm{Ca}$. Methylomirabilis' as well as anammox is dependent on nitrite. Oxygen is detrimental for all three processes (Strous et al. 1999b; Luesken et al. 2012; Guerrero-Cruz et al. 2018). Although several studies have enriched combinations of $\mathrm{N}$ damo bacteria and archaea or N-damo archaea and anammox bacteria, few studies have been designed to enrich all three groups from the same source material (Arshad et al. 2017; Stultiens et al. 2019). In order to successfully start such timeconsuming long-term enrichment cultures, screening of the inoculum for the presence of markers. Genes of N-damo and anammox microorganisms would be advantageous (Luesken et al. 2011c; Bhattacharjee et al. 2016; Zhu et al. 2017). Previous metagenome analyses have revealed that ' $\mathrm{Ca}$. Methylomirabilis' uses an intra-aerobic mechanism in which oxygen is produced via a putative nitric oxide dismutase (nod gene) and subsequently used for methane oxidation via the particulate methane monooxygenase (pmoA gene) complex (Ettwig et al. 2010; Versantvoort et al. 2018). Sequencing of the genome of the ' $\mathrm{Ca}$. Methanoperedens' indicated the presence of a reverse pathway of methanogenesis via methylcoenzyme $\mathrm{M}$ reductase $(m c r \mathrm{~A})$, nitrate reductase, and multiheme protein complexes possibly involved in extracellular electron transfer (Ettwig et al. 2010;; Haroon et al. 2013; Arshad et al. 2015; Ettwig et al. 2016; Vaksmaa et al. 2017a; Gambelli et al. 2018). The blueprint of anammox bacteria contains many interesting and diagnostic features including hydrazine synthase (hzsA) and hydrazine dehydrogenase, multiheme protein complexes, and nitrite and nitrate reductases (Strous et al. 2006; Kartal et al. 2011).

Using specific primers for (1) anammox $16 \mathrm{~S}$ rRNA or $h z s A$ genes (Schmid et al. 2001; Harhangi et al. 2012); (2) the $p m o A$ gene of ' $\mathrm{Ca}$. Methylomirabilis' (Luesken et al. 2011c); and (3) $m c r A$ genes of anaerobic methanogens and methanotrophs (Vaksmaa et al. 2017b), we screened the biomass of a wastewater plant treating brewery effluents for the presence of $\mathrm{N}$ damo and anammox microorganisms. After ' $C a$. Methylomirabilis' and anammox diagnostic genes were detected, we used the biomass to start an anaerobic sequencing batch bioreactor that was continuously fed with nitrate, nitrite, ammonium, and methane. After establishing activity of Ndamo and anammox, the total DNA of the new enrichment culture was sequenced, assembled, and binned into draft genomes. The draft genomes of $\mathrm{N}$-damo and anammox were annotated and analyzed. The enriched microbial community was further characterized by fluorescence in situ hybridization (FISH) microscopy and activity assays. 


\section{Materials and methods}

\section{Biomass}

In a previous study, 9 WWTP plants in the Netherlands were screened by a nested PCR approach for the presence of the 16S rRNA of N-damo bacteria (Luesken et al. 2011c). One of them, the WWTP in Lieshout $\left(51^{\circ} 51^{\prime} \mathrm{N}, 5^{\circ} 61^{\prime} \mathrm{E}\right)$ treats industrial brewery effluent using UASB reactors followed by a Pasveer-type carrousel at moderate temperatures and intermittent aeration. Sludge from the latter compartment contained the largest diversity of $\mathrm{N}$-damo bacteria. Therefore, biomass of the carrousel sludge of this plant, sampled in November 2013, January 2014, and April 2014, was used for a more extended molecular survey and activity tests. After detection of relevant marker genes of $\mathrm{N}$-damo and anammox microorganisms, $400 \mathrm{~mL}$ of the WWTP carrousel sludge (sampled in August 2014) was used as inoculum to enrich for these microorganisms in a continuous bioreactor. The first 3 days of enrichment, oxygen was introduced into the system to mineralize excess sludge; as soon as dissolved oxygen increased, air supply was switched off, and the reactor was operated anoxically by sparging with methane $/ \mathrm{CO}_{2}$ mixture.

\section{Batch activity tests}

In addition to the molecular survey and to couple these results to physiological tests, we also determined the potential of the Lieshout sludge for aerobic ammonium and nitrite oxidation, denitrification, and anammox activity. Sludge from the carrousel of the Lieshout WWTP was allowed to settle, decanted, and washed 2-3 times with 3-morpholinopropane-1-sulfonic acid (MOPS) buffered $\mathrm{N}$-free mineral salt medium ( $\mathrm{pH} 7.4$ ) to remove excess dissolved organic carbon. Subsequently, the sludge was diluted 6 times with MOPS buffered N-free mineral salt medium ( $\mathrm{pH}$ 7.4). For all batch incubations, $60 \mathrm{~mL}$ of diluted sludge was transferred to $120-\mathrm{mL}$ serum bottles. The headspace of the bottles used for anaerobic incubations (Table 1) was exchanged with argon by 3 cycles of vacuum and gassing followed by 10 min flushing. Next, substrates were added according to Table 1. All treatments were performed in duplicate. Incubations were performed at $30{ }^{\circ} \mathrm{C}$ and shaking at $180 \mathrm{rpm}$. Every $2 \mathrm{~h}$, the availability of nitrite and nitrate was checked by means of Merck test strips, and liquid samples were taken, centrifuged for $1 \mathrm{~min}$ at maximum speed, and stored at $-20{ }^{\circ} \mathrm{C}$ for further analysis.

\section{Establishment of an $\mathrm{N}$-damo and anammox enrich- ment culture}

Lieshout carrousel sludge ( $400 \mathrm{~mL})$ was used to inoculate a $7 \mathrm{~L}$ sequencing batch reactor (SBR) containing $4 \mathrm{~L}$ medium. Every SBR cycle consisted $10 \mathrm{~h}$ and $40 \mathrm{~min}$ of constant medium supply, $20 \mathrm{~min}$ of settling, and 1-h removal of excess liquid. The first 3-day oxygen was supplied during the filling period to mineralize excess sludge. Dissolved oxygen in the reactor was always below the detection limit of the Clarketype oxygen sensor $(<0.5 \mu \mathrm{M})$. After 3 days, the air supply was turned off, and the culture was kept anoxic by continuous flushing with $\mathrm{CH}_{4} / \mathrm{CO}_{2}\left(95 \% / 5 \%, 10 \mathrm{~mL} \mathrm{~min}^{-1}\right)$. The culture was fed with synthetic medium (Stultiens et al. 2019) containing sufficient iron, copper, and cerium as trace elements, and was further supplemented with $5 \mathrm{mM} \mathrm{NO}_{3}{ }^{-}, 0-8 \mathrm{mM} \mathrm{NO}_{2}{ }^{-}$, and $0.5-5 \mathrm{mM} \mathrm{NH}_{4}{ }^{+}$. The $\mathrm{NO}_{2}{ }^{-}$and $\mathrm{NH}_{4}{ }^{+}$concentration of the medium was gradually increased following the rising consumption of these substrates by the biomass of the culture. The amount of medium fed per day was adjusted to the nitrite and nitrate consumption of the culture. The medium vessel was flushed with $\mathrm{Ar} / \mathrm{CO}_{2}\left(95 \% / 5 \%, 10 \mathrm{~mL} \mathrm{~min}{ }^{-1}\right)$. The $\mathrm{pH}$ was maintained at 7.3 by $\mathrm{KHCO}_{3}$ addition. The reactor was equipped with $\mathrm{pH}$ and Clarke-type dissolved oxygen sensors and connected to an ADI1010 bio-controller (Applikon Biotechnology BV, Schiedam, the Netherlands). The SBR was operated a room temperature $\left(20 \pm 1{ }^{\circ} \mathrm{C}\right)$ and was stirred by means of a turbine stirrer. Stirring speed was $80 \mathrm{rpm}$ in the first 2 months, after which it was increased to $150 \mathrm{rpm}$. During the removal period, the liquid volume in the bioreactor was maintained by a level-controlled effluent pump, and washedout biomass was retained within the system by an external settler. In addition, a gas-buffer bottle $(5 \mathrm{~L})$ filled with Argon prevented oxygen from entering the reactor. Influent
Table 1 Substrate additions during batch activity assays

\begin{tabular}{lll}
\hline Activity & Aerobic/anaerobic & Substrates \\
\hline Anammox & Anaerobic & $2 \mathrm{mM} \mathrm{NH}_{4} \mathrm{Cl}+2 \mathrm{mM} \mathrm{NaNO}_{2}$ \\
Aerobic ammonium oxidation & Aerobic & $5 \mathrm{mM} \mathrm{NH}_{4} \mathrm{Cl}+\mathrm{O}_{2}$ \\
Ammonium oxidation (neg. control) & Anaerobic & $5 \mathrm{mM} \mathrm{NH}_{4} \mathrm{Cl}$ \\
Nitrite oxidation & Aerobic & $2 \mathrm{mM} \mathrm{NaNO}_{2}+\mathrm{O}_{2}$ \\
Nitrite oxidation (neg. control) & Anaerobic & $2 \mathrm{mM} \mathrm{NaNO}_{2}$ \\
Denitrification & Anaerobic & $5 \mathrm{mM} \mathrm{NaCH}_{3} \mathrm{COO}+5 \mathrm{mM} \mathrm{NaNO}_{3}$ \\
Denitrification (neg. control) & Anaerobic & $5 \mathrm{mM} \mathrm{NaNO}_{3}$ \\
\hline
\end{tabular}


and effluent samples were taken on a regular basis, centrifuged for $5 \mathrm{~min}$ at $20,000 \times \mathrm{g}$ and the supernatant was stored at $-20{ }^{\circ} \mathrm{C}$ until further analysis.

\section{Reactor activity assays}

The nitrate, ammonium, nitrite, and methane consumption rates of the anaerobic enrichment culture were determined several times with the whole reactor in batch mode. For the assays that included determination of methane consumption rates, the SBR cycle, influent flow, and $\mathrm{CH}_{4}$ inflow were stopped when the reactor level was 4.6-4.7 L. The stirring was stopped and the headspace of the reactor was flushed with Argon. Subsequently, the headspace was closed off and stirring was resumed $(150 \mathrm{rpm})$. Fifty milliliters $\mathrm{CO}_{2}$ was added to the headspace, and the gasses in the liquid and headspace were allowed to equilibrate for $18 \mathrm{~h}$. After $18 \mathrm{~h}$, supplements were added as described in Table 2. Gas and liquid samples were taken in regular intervals for further analysis. Anammox activity was evaluated separately in a similar assay. For this assay, after flushing the headspace with Argon for $30 \mathrm{~min}$, the complete reactor was flushed for $2.5 \mathrm{~h}$ with $\mathrm{Ar} / \mathrm{CO}_{2}(95 \% / 5 \%$, $10 \mathrm{~mL} \mathrm{~min}^{-1}$ ). During this flushing period, stirring continued (150 rpm). Subsequently, the headspace was closed off and supplements were added as described in Table 2. Gas and liquid samples were taken in regular intervals for further analysis. Liquid samples taken during these reactor activity tests were centrifuged for $1 \mathrm{~min}$ at $20,000 \times \mathrm{g}$ and the supernatant was stored at $-20{ }^{\circ} \mathrm{C}$ until further analysis.

\section{Analytical methods}

For reactor samples and samples taken during activity assays, ammonium was determined colorimetrically using a modified orthophataldialdehyde assay and nitrite by the Griess reaction (Ettwig et al. 2008). Nitrate was measured with the NOA280i nitric oxide analyzer (GE Analytical Instruments, Manchester, UK). Nitrate is first converted into nitric oxide at $95^{\circ} \mathrm{C}$ using a saturated solution of $\mathrm{VCl}_{3}$ in $\mathrm{HCl}$. The produced nitric oxide is subsequently detected and quantified by the nitric oxide analyzer. For samples taken during the reactor activity assays, nitrate was determined in two steps: first, the Griess reaction was performed to determine the nitrite concentration in the samples. Subsequently, the nitrate was reduced to nitrite by adding saturated $\mathrm{VCl}_{3}$ solution and incubating the samples for $30 \mathrm{~min}$ at $60^{\circ} \mathrm{C}$. The produced nitrite reacted immediately in the Griess assay and gave a combined signal for nitrite and nitrate. Methane was measured using gas chromatography (HP 5890 gas chromatograph with a flame ionization detector, Porapak Q column). $\mathrm{N}_{2}$ and $\mathrm{N}_{2} \mathrm{O}$ production was analyzed using gas chromatography (Agilent 6890, Porapak Q column, $80{ }^{\circ} \mathrm{C}$ ) in combination with mass spectrometry (Agilent 5975c, quadruple inert MS; Ettwig et al. 2010; Arshad et al. 2017).

\section{Fluorescence in situ hybridization}

Biomass samples $(2 \mathrm{~mL})$ from the anaerobic methane- and ammonium-oxidizing coculture were taken on day 202 and 408. For each time point, multiple samples $(>5)$ were processed for FISH analysis. The samples were centrifuged for $5 \mathrm{~min}$ at $20,000 \times \mathrm{g}$. The pellets were washed with $1 \mathrm{~mL}$ phosphate-buffered saline (PBS; $10 \mathrm{mM} \mathrm{Na} \mathrm{HPO}_{4} /$ $\mathrm{NaH}_{2} \mathrm{PO}_{4} \mathrm{pH} 7.5$ and $130 \mathrm{mM} \mathrm{NaCl}$ ) and fixed in paraformaldehyde. Subsequently, hybridization of $\mathrm{Cy} 3, \mathrm{Cy} 5$, or FLUOS fluorescently labeled probes was performed as described before (Arshad et al. 2017; Ettwig et al. 2008). Eub 338, Eub 338 II, and Eub 338 III were mixed in equimolar solution (Eubmix) and used as such. Probes to visualize anammox bacteria (AMX820), 'Ca. Methylomirabilis' bacteria (DBACT1027), and all Bacteria (Eubmix) were utilized to visualize different groups of microorganisms within the anaerobic methane- and ammonium-oxidizing culture (Amann et al. 1990; Schmid et al. 2001; Raghoebarsing et al. 2006; Daims et al. 1999). All samples were counterstained with DAPI. Slides were examined and images obtained by utilization of a Zeiss Axioplan 2 epifluorescence microscope
Table 2 Substrates added in the reactor assays

\begin{tabular}{lcl}
\hline Reactor assay & Time & Added substrates* \\
\hline Nitrate and methane consumption & 1254 & Not applicable* \\
Nitrate, nitrite, and methane consumption & 1265 & $0.5 \mathrm{mM} \mathrm{NO}_{2}^{-*}$ \\
Nitrate, nitrite, ammonium, and methane consumption & 1268 & $0.5 \mathrm{mM} \mathrm{NO}_{2}^{-}$ \\
Nitrate, nitrite, and ammonium consumption (anammox) & & $0.5 \mathrm{mM} \mathrm{NH}_{4}^{+*}$ \\
& 1271 & $0.5 \mathrm{mM} \mathrm{NO}_{2}^{-}$ \\
& & $0.5 \mathrm{mM} \mathrm{NH}_{4}^{+* *}$ \\
\hline
\end{tabular}

Time, the number of cultivation days

* Methane and nitrate were not added separately but were still present in the liquid of the bioreactor

**Nitrate was not added separately but was still present in the liquid of the bioreactor 
equipped with a digital camera, in combination with the Axiovision software package (Zeiss,Germany).

\section{Metagenomic analysis}

DNA from all samples was isolated by three different methods: (1) PowerSoil DNA Isolation Kit (MO BIO Laboratories Inc., Carlsbad, CA, USA), (2) the ammonium acetate extraction method (Kowalchuk et al. 2004), and (3) the CTAB extraction method (Zhou et al. 1996). In total, $125 \mathrm{ng}$ of isolated genomic DNA was sheared for 9 min using a Bioruptor® UCD-200 (Thermo Fisher Scientific Inc., USA). Libraries were prepared using an Ion Plus Fragment library kit (Thermo Fisher Scientific Inc., USA). For size selection of the adapter ligated fragments, an E-Gel® electrophoresis system was used with a $2 \%$ E-Gel ${ }^{\circledR}$ SizeSelect ${ }^{\mathrm{TM}}$ agarose gel (Life Technologies, Bleiswijk, the Netherlands). Eight cycles of amplification of the size-selected fragments were performed. The concentrations and fragment lengths of the libraries were determined with a Bioanalyzer® 2100 and High Sensitivity DNA Kit (Agilent Technologies, Santa Clara, CA, USA). The library was diluted to a final concentration of $26 \mathrm{pM}$ for emulsion PCR. Emulsion PCR was performed using an Ion OneTouch $^{\mathrm{TM}} 2$ Instrument and Ion PGM ${ }^{\mathrm{TM}}$ Template OT2 400 Kit (Thermo Fisher Scientific Inc., USA). The templatepositive Ion Sphere ${ }^{\mathrm{TM}}$ Particles (ISPs) were enriched using the Ion One Touch ${ }^{\mathrm{TM}}$ ES and loaded on an Ion $318^{\mathrm{TM}}$ v2 Chip, and sequenced using an Ion PGM ${ }^{\mathrm{TM}}$ Sequencing $400 \mathrm{Kit}$ with 850 nucleotide flows. After sequencing, all raw reads were imported into CLC Genomics Workbench version 8.5.1 (QIAGEN Aarhus A/S, Denmark) for initial data analysis, including trimming of low-quality and short reads (cut-off value of 200 nucleotides), followed by assembly of the reads (word size automatic, bubble size 5000). The raw reads of metagenome sequencing are submitted to the Sequence Read Archive (SRA) under project number PRJEB37137. An additional assembly using SPAdes (Bankevich et al. 2012) was performed using standard parameters for singleend reads. All contigs below 1000 bp were discarded from the assembly. To extract the contigs of the anaerobic methanotrophs and anammox, the contigs were binned based on GC content and coverage using RStudio (RStudio Team 2015 ) with the GC script. The contigs of ' $\mathrm{Ca}$. Methylomirabilis' or anammox bacteria were extracted from all assemblies, and reads mapping to contigs were reassembled in CLC (word size 30, bubble size 5000). The completeness of the draft genomes and contamination were assessed by CheckM (Parks et al. 2015). BLAST was used to search for key genes in the ' $\mathrm{Ca}$. Methylomirabilis' and anammox genomes. The contigs containing marker genes were manually curated. The curated contigs were checked using the visualization and annotation tool Artemis (Rutherford et al. 2000).

\section{Results}

\section{Performance Lieshout WWTP}

The carrousel of the WWTP Lieshout is a low-loaded system that receives on average $4700 \mathrm{~m}^{3}$ effluent per day from 3 UASB reactors. The total nitrogen supply to the carrousel is about $216 \mathrm{~kg} \mathrm{~N}$ per day and the average ammonium and nitrate concentrations of the UASB effluent are 5.4 and $0.9 \mathrm{mg} \mathrm{N} \mathrm{L}^{-1}$, respectively. After treatment in the carrousel, the ammonium and nitrate concentrations are 0.7 and $1.2 \mathrm{mg} \mathrm{N} \mathrm{L}^{-1}$, indicating presence of both nitrifying and denitrifying microorganisms. Therefore, the potential rates for ammonium, nitrite, and nitrate conversions were measured in batch tests (Table 3 ). The $4.7 \mathrm{mg} \mathrm{N} \mathrm{L}^{-1}$ ammonium remov$\mathrm{al}$ in the carrousel results in a removal rate of about $0.33 \mathrm{mmol}$ $\mathrm{NH}_{4}{ }^{+} \mathrm{L}^{-1}$ day ${ }^{-1}$ and is in good agreement with the potential ammonium-oxidation $\left(0.26-0.3 \mathrm{mmol} \mathrm{NH}_{4}{ }^{+} \mathrm{L}^{-1}\right.$ day $\left.^{-1}\right)$ measured in the batch tests. The nitrite-oxidation and nitrate reduction potential exceed these values 2 - to 5 -fold, indicating that aerobic ammonium oxidation might be the limiting step in the nitrogen removal in WWTP Lieshout. N-damo and anammox activity could not be detected within $36 \mathrm{~h}$ of incubation, possibly because of high back ground denitrification rates (Table 3).

\section{Molecular survey Lieshout sludge}

DNA of the Lieshout sludge was extracted and sequenced using Ion Torrent Technology. Extraction of 16S rRNA gene sequences (Fig. 1a) of the total metagenome yielded 2801 reads, the majority belonging to Proteobacteria (38\%), Bacteroidetes (13\%), Chloroflexi (12\%), and Firmicutes (10\%). Planctomycetes comprised $6 \%$ of the $16 \mathrm{~S}$ rRNA reads, of which many corresponded to the order of Phycisphaerales. In the metagenome, no $16 \mathrm{~S}$ rRNA reads belonging to anammox bacteria were retrieved, while $23(0.8 \%)$ reads were affiliated to Nitrosomonas and $25(0.9 \%)$ to aerobic methanotrophs (Methylococcocaea). Despite the absence of anammox reads in the metagenome, $16 \mathrm{~S}$ rRNA and hydrazine synthase ( $h z s \mathrm{~A}$ ) genes could readily be amplified using DNA from the Lieshout carrousel sludge as a template. The majority of anammox clones were affiliated to ' $\mathrm{Ca}$. Brocadia' (Supplementary Fig. S1). Also, the pmoA gene of ' $\mathrm{Ca}$. Methylomirabilis' could be amplified from the sludge DNA, and the diversity of these N-damo bacteria (Supplementary Fig. S2) was similar to previous studies based on nested $16 \mathrm{~S}$ rRNA gene amplifications (Luesken et al. 2011c). The amplification of the mcrA gene showed a large diversity of methanogens (Supplementary Fig. S3) probably seeded into the carrousel from the UASB effluent. One of the 16 analyzed $m c r$ A clones was affiliated to N-damo ' $C a$. Methanoperedens' archaea. 
Table 3 Nitrifying and denitrifying potential of Lieshout sludge

\begin{tabular}{|c|c|c|c|}
\hline \multirow[t]{2}{*}{ Activity tested } & \multicolumn{3}{|c|}{ Removal rates $\left(\mathrm{mmol} \mathrm{N} \mathrm{L}^{-1}\right.$ day $\left.^{-1}\right)$} \\
\hline & Nov-2013 & Jan-2014 & Apr-2014 \\
\hline \multicolumn{4}{|l|}{ Ammonium oxidation } \\
\hline Oxygen-dependent nitrite formation & 0.9 & 1.2 & 0.5 \\
\hline Oxygen-dependent nitrite + nitrate formation & 3.3 & 4.9 & Not determined \\
\hline \multicolumn{4}{|l|}{ Nitrite oxidation } \\
\hline Oxygen-dependent nitrite removal & 2.8 & 4.1 & 15 \\
\hline \multicolumn{4}{|l|}{ Denitrification } \\
\hline Anoxic nitrate removal & 48 & 50 & 46 \\
\hline
\end{tabular}

\section{Enrichment of $\mathrm{N}$-damo and anammox bacteria}

As anammox and N-damo bacteria were present in relatively low abundance, the excess biomass in the sludge needed to be mineralized as a strategy to reduce enrichment times. The first 3 days after inoculation of an anaerobic SBR, air was introduced into the system to convert easily degradable carbon and biomass. After the dissolved oxygen concentration started to increase, the air supply was turned off, and the SBR was fed with methane, ammonium, nitrate, and nitrite under anoxic conditions. After 100 days, the $\mathrm{N}$-load to the reactor could gradually be increased to $5 \mathrm{mM} \mathrm{NH}_{4}{ }^{+}, 8 \mathrm{mM} \mathrm{NO}_{2}{ }^{-}$, and $5 \mathrm{mM} \mathrm{NO}_{3}{ }^{-}$resulting in nitrite and ammonium consumption rates of $1.25 \mathrm{mmol} \mathrm{L}^{-1}$ day $^{-1}$ and $1 \mathrm{mmol} \mathrm{L}^{-} 1 \mathrm{day}^{-1}$, respectively (Fig. 2). When the reactor was run in batch mode without ammonium present, nitrite consumption $\left(0.12 \mathrm{mmol} \mathrm{h}^{-1}\right)$ at the expense of methane could readily be observed (Fig. 3a). In the absence of methane, anammox bacteria converted nitrite $\left(0.5 \mathrm{mmol} \mathrm{h}^{-1}\right)$ with ammonium as electron donor (Fig. 3b), indicating that anammox converted about $80 \%$ of the nitrite fed to the reactor while $\mathrm{N}$-damo was responsible for the remaining $20 \%$.

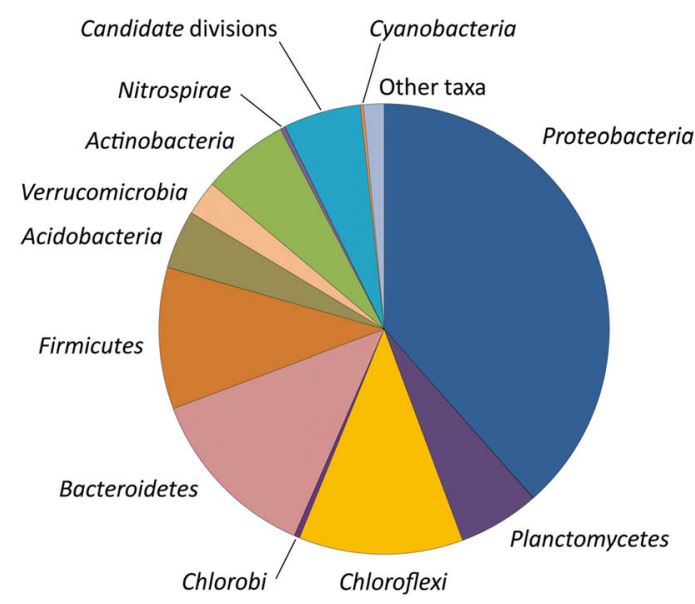

\section{Carrousel Sludge}

The fate of ${ }^{15} \mathrm{~N}$-labeled substrates was measured in a reactor batch test. According to expectation (Ettwig et al. 2010), labeled ${ }^{15} \mathrm{~N}$-nitrite was predominantly converted to ${ }^{30} \mathrm{~N}_{2}$ gas (Fig. 4a) by the N-damo bacteria. In the anammox test, most of the ${ }^{15} \mathrm{~N}$ label of ammonium was converted in to ${ }^{29} \mathrm{~N}_{2}$ following the described stoichiometry (Strous et al. 1999b). In both incubation, some ${ }^{28} \mathrm{~N}_{2}$ from unlabeled nitrate was produced presumably via background denitrification, and therefore exact mass balanced could not be made.

In accordance with the nitrogen conversions in reactor batch tests, 'Ca. Methylomirabilis' and anammox bacteria were the dominant members of the community as estimated from FISH microscopy (Fig. 5) and metagenomic analysis after 14 months of operation.

\section{Metagenomic analysis and classification based on the 16S rRNA gene}

After 4.5 months of enrichment, genomic DNA was extracted and sequenced by Ion Torrent Technology to investigate enrichment of anaerobic ammonia and methane-oxidizing

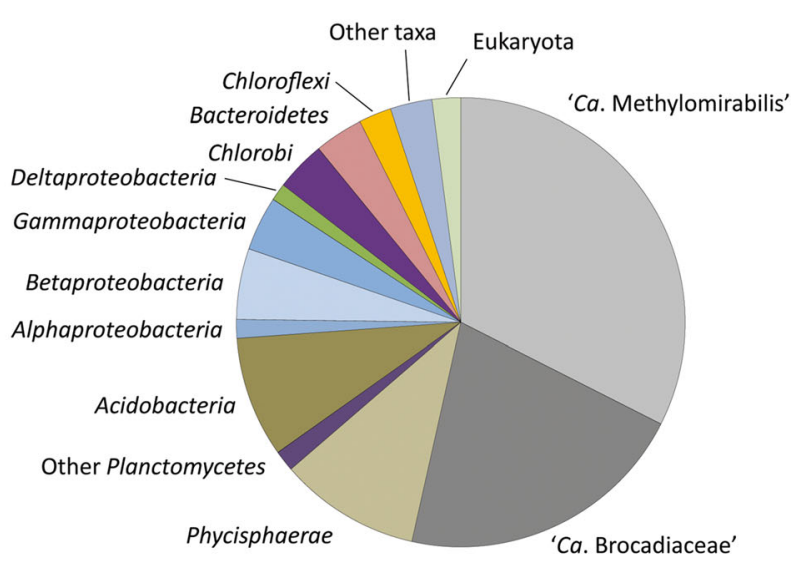

Fig. 1 Percentages of reads containing parts of 16S rRNA genes for different phyla extracted from the metagenomes of a the original Lieshout WWTP sludge and $\mathbf{b}$ the enrichment bioreactor metagenome after 14 months of operation, by mapping on the Silva database 


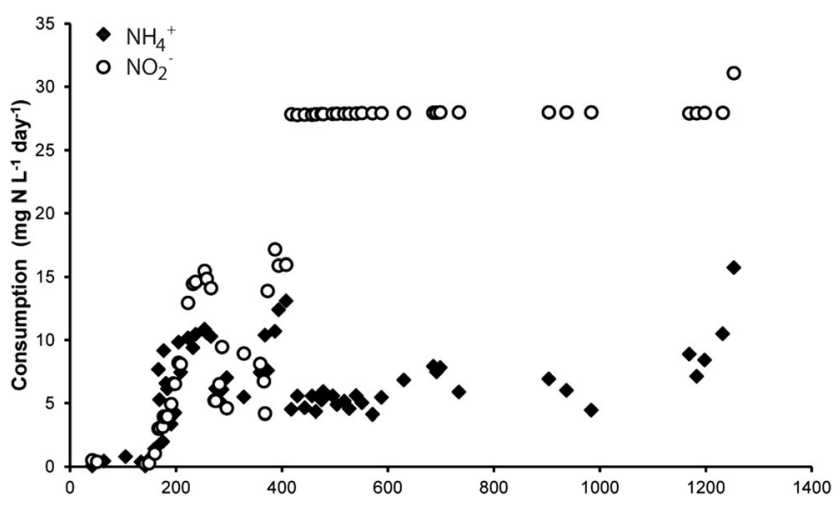

Fig. 2 Conversion of ammonium and nitrite in the enrichment of N-damo and anammox from WWTP Lieshout

microorganisms. Not much changes were observed compared with the original sludge and we decided to continue the enrichment. After 14 months of enrichment, DNA was extracted once more to analyze the 16S rRNA gene diversity and to potentially assemble draft genomes. From this metagenome, 1996 16S rRNA reads were extracted. The phylogenetic classifications for groups with an abundance of greater than $1 \%$ of the total number of 16S rRNA gene reads are shown in Fig. $1 \mathrm{~b}$. More than $60 \%$ of the $16 \mathrm{~S}$ rRNA gene reads belonged to three dominant groups: Brocadiaceae (21\%), N-damo ' $\mathrm{Ca}$. Methylomirabilis' bacteria (32\%), and Phycisphaera-like Planctomycetes (10\%), confirming the results of FISH microscopy.

The Ion Torrent reads were assembled into contigs, and contigs were binned by differential coverage and GC content. The binning resulted in 6 high-quality draft genomes (above 92\% completeness; Table 4). Two draft genomes (Bins 1 and 2) represented distinct ' $\mathrm{Ca}$. Methylomirabilis' species, closely related to ' $\mathrm{Ca}$. M. oxyfera' (Bin2) and ' $\mathrm{Ca}$. M. lanthanidiphila' (Bin1). Three bins showed high similarity to ' $\mathrm{Ca}$. Brocadia' anammox species and further refinement was hampered by microdiversity differences. Interestingly, one draft genome (Bin6) represented an unknown genus, most closely related to the Phycisphaera species within the phylum Planctomycetes.

The ' $\mathrm{Ca}$. Methylomirabilis' draft genomes (Bins 1 and 2) contained the diagnostic pmoCAB, xoxF, nirS, and putative NO dismutase genes. The $p m o A$ marker genes encoding a subunit of the membrane-bound methane monooxygenase had $99.2 \%$ and $97.1 \%$ identity at the protein level to ' $\mathrm{Ca}$. M. oxyfera' and ' $\mathrm{Ca}$. M. lanthanidiphila,' respectively. We also identified a gene encoding the lanthanide-dependent methanol dehydrogenase $(x o x F)$ in both genomes with $93-98 \%$ identity at the protein level to ' $\mathrm{Ca}$. Methylomirabilis' species. Genes encoding the canonical calcium-dependent methanol dehydrogenase were absent in both genomes. Genes encoding the putative nitric oxide dismutase (nod) showed $85-90 \%$ amino acid identity to ' $\mathrm{Ca}$. Methylomirabilis' species. The identified cd1 cytochrome nitrite reductase (nirS) had 92-99\% identity to other ' $\mathrm{Ca}$. Methylomirabilis' species.

The genomes assembled in Bins 3, 5, and 8 were determined to belong to the Planctomycetes phylum by the CheckM taxonomy assessment and most closely related to the anammox bacterium ' $\mathrm{Ca}$. Brocadia fulgida.' This points to microdiversity of this species with bin3 as the most dominant (Supplementary Fig. S4). The genes encoding the crucial proteins involved in the anammox process were identified in the bins. These proteins include the hydrazine synthase, the hydrazine dehydrogenase, and multiple hydroxylamine oxidoreductases. The phylogenetic functional marker genes $h z s A$ (Harhangi et al. 2012) encoding the alpha subunit of the hydrazine synthase had $89-93 \%$ identity on protein level to ' $\mathrm{Ca}$. Brocadia' species.

The genome present in Bin6 was the only bin with complete 16S rRNA and 23S rRNA genes on one of the contigs. A BlastN search with the 16S rRNA gene revealed 99.3\% identity with clones from anammox reactors treating wastewater (NCBI, unpublished sequences). The closest cultured representative with $92.4 \%$ identity was Phycisphaerae bacterium RAS2 isolated from a fish tank biofilter enrichment (Wiegand et al. 2020). The Prokka annotated genome does not reveal the potential for an autotrophic life style.

\section{Discussion}

Nitrate- and nitrite-dependent anaerobic oxidation of methane (N-damo) was discovered a decade ago, but the ecophysiological characterization of the microorganisms involved has been hindered by the slow growth of the responsible organisms (Raghoebarsing et al. 2006; Ettwig et al. 2010; Haroon et al. 2013). The N-damo microorganisms 'Candidatus
Fig. 3 a Conversion of methane and nitrite by N-damo. b Conversion of ammonium and nitrite by anammox in the Lieshout N-damo and anammox enrichment culture after roughly 42 months of operation
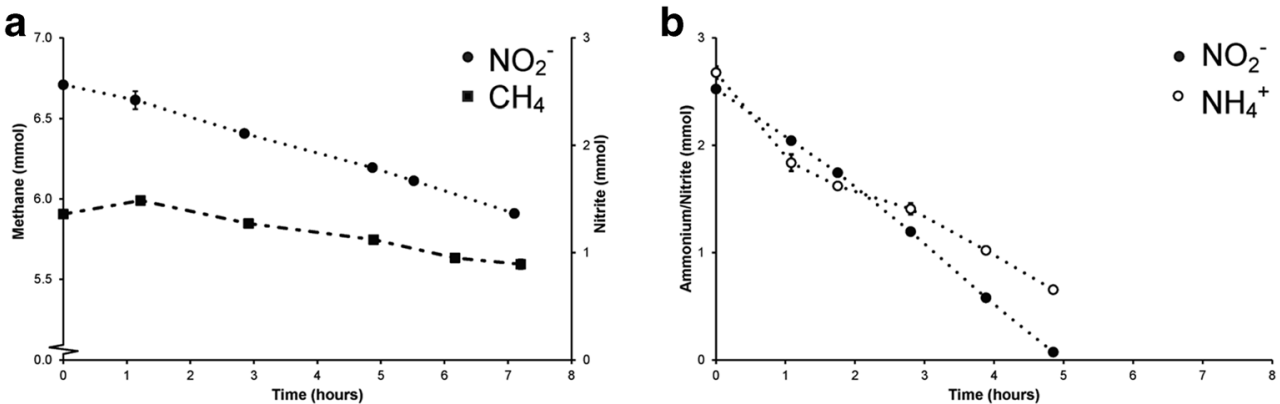


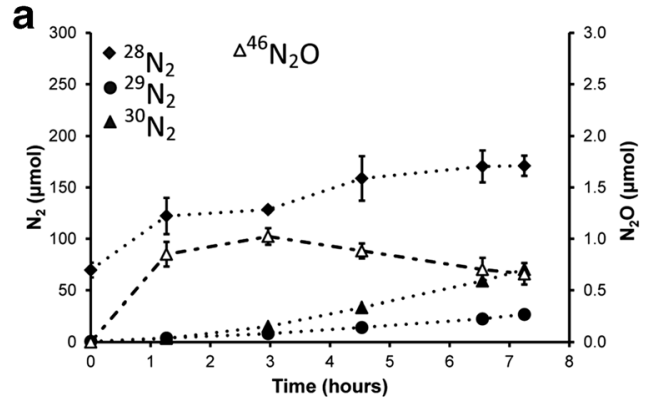

Fig. 4 a Labeled dinitrogen gas production from ${ }^{15} \mathrm{~N}$ nitrite with methane as electron donor by $\mathrm{N}$-damo, without presence of ammonium. $\mathbf{b}$ Labeled dinitrogen gas production from ${ }^{15} \mathrm{~N}$ ammonium with nitrite by anammox,

Methanoperedens nitroreducens' archaea and ' $C a$. Methylomirabilis' bacteria have been detected in various freshwater sediments (Welte et al. 2016). In this study, we started an enrichment culture fed with methane, ammonium, nitrate, and nitrite using carrousel sludge from a WWTP treating brewery effluent, as the inoculum. Based on activity measurements, FISH microscopy, and metagenome analyses after 14 months, the enrichment was dominated by ' $\mathrm{Ca}$. Methylomirabilis' species and anammox bacteria. Previous enrichments were fed with mixtures of nitrite and nitrate without ammonium, to ensure that anammox bacteria would not outcompete ' $C a$. Methylomirabilis' bacteria for nitrite (Luesken et al. 2011b; Shi et al. 2013; Hu et al. 2015; Ding et al. 2017; Vaksmaa et al. 2017b). Although the inoculum sludge had no detectable anammox or N-damo activity within $36 \mathrm{~h}$, and only one $16 \mathrm{~S}$ rRNA gene read resembling anammox could be detected in the initial metagenome, the diagnostic genes $h z s A$ and $p m o A$ could be readily amplified using DNA extracted from the sludge as a template. This indicated that the Lieshout carrousel sludge does harbor indigenous populations of $\mathrm{N}$-damo and anammox bacteria and could serve as start-up material when large-scale installation need to be seeded (van Kessel et al. 2018). Indeed, after a

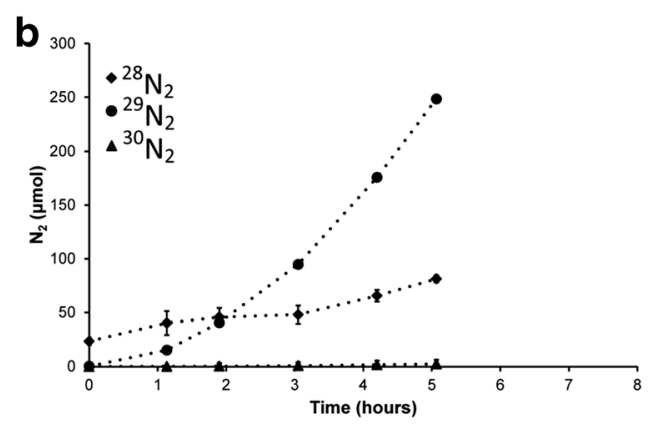

without methane present, in the Lieshout N-damo and anammox enrichment culture after 42 months of operation

start-up phase of about 100 days, an increasing consumption of nitrite, methane, and ammonium could be observed, and ultimately anammox and $\mathrm{N}$-damo bacteria were the key players of the microbial community. The start-up phase was relatively short, as previous enrichments obtained from a minerotrophic peatland only showed significant methane oxidation rates after 9 months and the original enrichment of $\mathrm{N}$-damo took more than a year before activity could be measured (Raghoebarsing et al. 2006; Zhu et al. 2012). In addition to substrate preference and availability, temperature has been implicated as a decisive factor in the outcome of $\mathrm{N}$-damo enrichments. In enrichments started from wastewater treatment sludge and lake sediments, a coenrichment of ' $\mathrm{Ca}$. Methylomirabilis' bacteria and ' $\mathrm{Ca}$. Methanoperedens' archaea was obtained at $35{ }^{\circ} \mathrm{C}$, whereas at $22{ }^{\circ} \mathrm{C}$, only $\mathrm{N}$-damo bacteria were enriched (Hu et al. 2009). Furthermore, ' $\mathrm{Ca}$. Methanoperedens' might be more sensitive to oxygen exposure (Guerrero-Cruz et al. 2018) than anammox and ' $\mathrm{Ca}$. Methylomirabilis' bacteria (Luesken et al. 2011a, 2012). As we used air in the first 3 days of enrichment to degrade excess sludge, we may have strongly inhibited the few ' $\mathrm{Ca}$. Methanoperedens' cells present and prevented their subsequent enrichment.

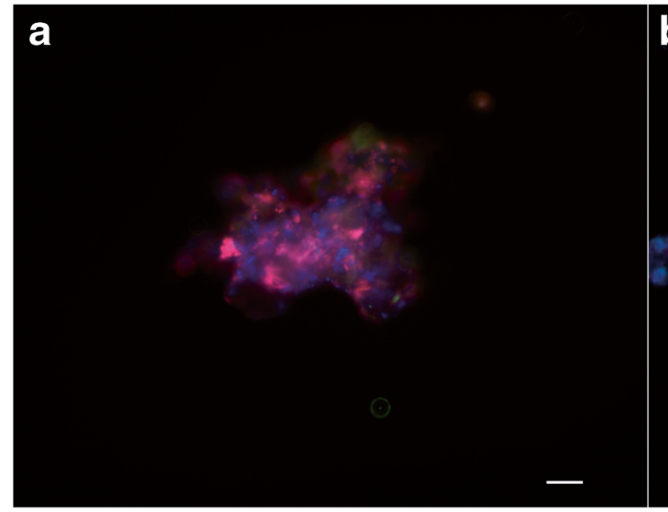

Fig. 5 FISH microscopy of the N-damo and anammox enrichment. a After 200 days, anammox bacteria were shown to be present (amx820, pink) whereas N-damo bacteria could not be visualized by FISH

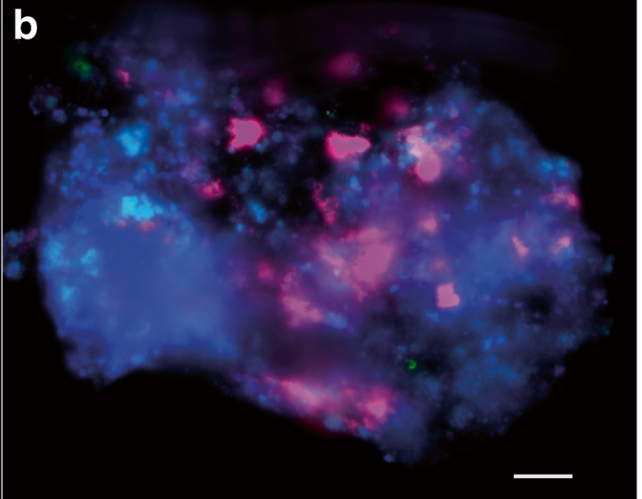

(damo1027, green). b After 408 days of enrichment, both anammox bacteria (amx820, blue) and $\mathrm{N}$-damo bacteria (damo1027, pink) were clearly present. Scale bar represents $20 \mu \mathrm{m}$ 
Table 4 Overview of bin quality, completeness, and characteristics

\begin{tabular}{|c|c|c|c|c|c|c|c|}
\hline Bin & Identity & $\begin{array}{l}\text { Completeness } \\
(\%)\end{array}$ & $\begin{array}{l}\text { Contamination } \\
(\%)\end{array}$ & $\begin{array}{l}\text { Number of } \\
\text { contigs }\end{array}$ & $\begin{array}{l}\text { Genome size } \\
\text { (bp) }\end{array}$ & Assembly & Binning methods \\
\hline 1 & 'Ca. Methylomirabilis' & 93.3 & 6.8 & 67 & $3,073,612$ & SPAdes & Metabat \\
\hline 2 & 'Ca. Methylomirabilis' & 95.4 & 1.7 & 60 & $2,866,557$ & CLC & Metabat, reassembly \\
\hline 3 & 'Ca. Brocadia' & 93.3 & 0 & 145 & $3,129,904$ & CLC & $\begin{array}{l}\text { Metabat, manual, } \\
\text { differential }\end{array}$ \\
\hline 5 & 'Ca. Brocadia' & 92.2 & 8.7 & 224 & $3,753,638$ & CLC & $\begin{array}{l}\text { Metabat, manual, } \\
\text { differential }\end{array}$ \\
\hline 6 & 'Phycisphaera' & 94.0 & 0 & 74 & $5,039,581$ & SPAdes & Metabat \\
\hline 8 & 'Ca. Brocadia' & 95.6 & 1.7 & 174 & $4,185,325$ & CLC & $\begin{array}{l}\text { Metabat, manual, } \\
\text { differential }\end{array}$ \\
\hline
\end{tabular}

In the present enrichment, the cell numbers estimated by FISH correlated well with the metagenome sequencing results for ' $\mathrm{Ca}$. Methylomirabilis,' with an abundance of about 30$40 \%$. Anammox seemed somewhat underrepresented in the metagenome $(20 \%)$ as activity measurements indicated that $80 \%$ of the nitrite conversion was accounted for by anammox activity. A similar observation was made previously where anammox converted about $70 \%$ of nitrite while FISH counts of anammox were less than $50 \%$ of the community (Luesken et al. 2011a). In our enrichment, there was always ammoniumlimiting to ensure that ' $\mathrm{Ca}$. Methylomirabilis' was not outcompeted by anammox (Hu et al. 2015). Incubations performed with the whole bioreactor revealed average ammonium oxidation and nitrite reduction after 14 months of $1 \mathrm{mmol} \mathrm{day}{ }^{-1} \mathrm{~L}^{-1}$ and $1.25 \mathrm{mmol} \mathrm{day}{ }^{-1} \mathrm{~L}^{-1}$, respectively which is a little bit lower compared with other enrichments (Luesken et al. 2011b; Hu et al. 2009; Vaksmaa et al. 2017b). With ${ }^{15} \mathrm{~N}$ isotope labeling experiments, we could show that in the absence of ammonium, a good methane-dependent nitrite conversion took place, and that the dominant product was the expected ${ }^{30} \mathrm{~N}_{2}$ gas (Ettwig et al. 2010). In the absence of methane, ${ }^{15} \mathrm{~N}$-labeled ammonium was combined with ${ }^{14} \mathrm{~N}$ nitrite to form ${ }^{29} \mathrm{~N}_{2}$ by anammox bacteria in accordance with the anammox reaction equation (Strous et al. 1999b). As not all unlabeled nitrate could be removed from the reactor, some background denitrification and $\mathrm{N}_{2} \mathrm{O}$ production was observed as well, as has been reported for other $\mathrm{N}$-damo enrichments (Vaksmaa et al. 2017b).

Metagenome analysis revealed that ' $\mathrm{Ca}$. Methylomirabilis,' 'Ca. Brocadia,' and a Phycisphaera-like bacterium were the dominant members of the community after 14 months of enrichments. The diagnostic genes for nitrite-driven anaerobic ammonium and methane oxidation were identified in the genomes assembled from the metagenome sequences. To elucidate the role of the Phycisphaera-like bacterium, further research will be needed. Recently, members of the family Phycisphaeraceae have been reported to be potentially involved in anaerobic ammonium oxidation coupled to the reduction of sulfate
(Sulfammox) or Fe(III) reduction (Feammox) in marine sediments (Rios-Del Toro et al. 2018a). Furthermore, representatives of this family were dominant in marine sediments from the eastern tropical North Pacific coast (Rios-Del Toro et al. 2018b). In this study, anaerobic ammonium oxidation linked to the microbial reduction of natural organic matter (NOM) fueled nitrogen loss. Other community members in our reactor system, mostly less than $5 \%$ of the population, belonged to various groups that have been reported before to be present in anaerobic methanotrophic enrichments (Vaksmaa et al. 2017b). In the enrichment, betaproteobacterial Rhodocyclaceae accounted for $6 \%$ and Comamonadaceae for $4 \%$ of the genome reads. They have both been implicated to perform denitrification, which may explain the observed back ground nitrate reduction, which was higher than expected based on the methane oxidation rate alone. Further significant numbers of Chloroflexi were present. They are obligate anaerobes that have previously been found in both anaerobic methanotrophic (Ettwig et al. 2009; Siniscalchi et al. 2015) and methanogenic enrichment cultures (Yamada et al. 2005; Gray et al. 2011; Liang et al. 2015). These Chloroflexi may degrade organic acids to formate, acetate, and hydrogen and feed the other community members (Hug et al. 2013).

In summary, we have enriched a N-damo and anammox coculture from the Lieshout WWTP carrousel sludge. Metagenome analysis, FISH microscopy, and activity test were in good agreement with each other that anammox contributed most to the nitrite conversion under ammonium limitation. The newly enriched co-culture will be used in future studies to unravel the ecophysiological properties of N-damo and anammox under oxygen limitation and investigate their potential role in more sustainable wastewater treatment systems.

Authors' contributions KS, MAHJvK, BK, MSMJ, and HOdC planned research. MAHJvK, BK, and HOdC supervised the project. KS, PF, and $\mathrm{CP}$ executed experiments. KS, MAHJvK, and HOdC analyzed data. TAvA performed sequencing and JF helped with analyzing the sequencing data. MSMJ, HOdC, and MAHJvK wrote the manuscript. All authors discussed results and commented on the manuscript. 
Funding information This work was supported by the Netherlands organization for Scientific Research, SIAM 024002002 and the European Research Council [ERC AG 339880 Eco_MoM] to MSMJ, and by the European Research Council ERC AG 669371 to HJMOdC. KST, MAHJvK, and SGC were supported by STW grant 13146. MAHJvK was further supported by an NWO Veni grant (016.veni.192.062). HOdC and BK were supported by the European Research Council (Advanced Grant VOLCANO 669371 and ERC starting grant GreenT 6400422).

Data availability The raw reads of the metagenome sequencing are submitted to the Sequence Read Archive (SRA) under project number PRJEB37137.

\section{Compliance with ethical standards}

Conflict of interest The authors declare that they have no conflict of interest.

Ethics statement This article does not contain any studies with human participants or animals performed by any of the authors.

Open Access This article is licensed under a Creative Commons Attribution 4.0 International License, which permits use, sharing, adaptation, distribution and reproduction in any medium or format, as long as you give appropriate credit to the original author(s) and the source, provide a link to the Creative Commons licence, and indicate if changes were made. The images or other third party material in this article are included in the article's Creative Commons licence, unless indicated otherwise in a credit line to the material. If material is not included in the article's Creative Commons licence and your intended use is not permitted by statutory regulation or exceeds the permitted use, you will need to obtain permission directly from the copyright holder. To view a copy of this licence, visit http://creativecommons.org/licenses/by/4.0/.

\section{References}

Amann RI, Krumholz J, Stahl DA (1990) Fluorescent-oligonucleotide probing of whole cells for determinative, phylogenetic, and environmental studies in microbiology. J Bacteriol 172:762-770

Arshad A, Speth DR, de Graaf RM, Op den Camp HJM, Jetten MSM, Welte CU (2015) A metagenomics-based metabolic model of nitrate-dependent anaerobic oxidation of methane by Methanoperedens-like Archaea. Front Microbiol 6:1423

Arshad A, Dalcin Martins P, Frank J, Jetten MSM, Op den Camp HJM, Welte CU (2017) Mimicking microbial interactions under nitratereducing conditions in an anoxic bioreactor: enrichment of novel Nitrospirae bacteria distantly related to Thermodesulfovibrio. Environ Microbiol 19(12):4965-4977

Bankevich A, Nurk S, Antipov D, Gurevich AA, Dvorkin M, Kulikov AS, Lesin VM, Nikolenko SI, Pham S, Prjibelski AD, Pyshkin AV, Sirotkin AV, Vyahhi N, Tesler G, Alekseyev MA, Pevzner PA (2012) SPAdes: a new genome assembly algorithm and its applications to single-cell sequencing. J Comput Biol 19(5):455-477

Bhattacharjee AS, Motlagh AM, Jetten MSM, Goel R (2016) Methane dependent denitrification- from ecosystem to laboratory-scale enrichment for engineering applications. Water Res 99:244-252

Cogert KI, Ziels RM, Winkler MKH (2019) Reducing cost and environmental impact of wastewater treatment with denitrifying methanotrophs, anammox, and mainstream anaerobic treatment. Environ Sci Technol 53(21):12935-12944
Daims H, Brühl A, Amann RI, Schleifer KH, Wagner M (1999) The domain-specific probe EUB338 is insufficient for the detection of all bacteria: development and evaluation of a more comprehensive probe set. Syst Appl Microbiol 22:434-444

Ding ZW, Lu YZ, Fu L, Ding J, Zeng RJ (2017) Simultaneous enrichment of denitrifying anaerobic methane-oxidizing microorganisms and anammox bacteria in a hollow-fiber membrane biofilm reactor. Appl Microbiol Biotechnol 101:437-446

Ettwig KF, Shima S, van de Pas-Schoonen KT, Kahnt J, Medema MH, Op den Camp HJM, Jetten MSM, Strous M (2008) Denitrifying bacteria anaerobically oxidize methane in the absence of Archaea. Environ Microbiol 10(11):3164-3173

Ettwig KF, van Alen T, van de Pas-Schoonen KT, Jetten MSM, Strous M (2009) Enrichment and molecular detection of denitrifying methanotrophic bacteria of the NC10 phylum. Appl Environ Microbiol 75(11):3656-3662

Ettwig KF, Butler MK, Le Paslier D, Pelletier E, Mangenot S, Kuypers MMM, Schreiber F, Dutilh BE, Zedelius J, de Beer D, Gloerich J, Wessels HJCT, van Alen T, Luesken F, Wu ML, van de PasSchoonen KT, Op den Camp HJM, Janssen-Megens EM, Francoijs KJ, Stunnenberg H, Weissenbach J, Jetten MSM, Strous M (2010) Nitrite-driven anaerobic methane oxidation by oxygenic bacteria. Nature 464(7288):543-548

Ettwig KF, Zhu B, Speth DR, Keltjens JT, Jetten MSM, Kartal B (2016) Archaea catalyze iron-dependent anaerobic oxidation of methane. Proc Natl Acad Sci U S A 113(45):12792-12796

Fan SQ, Xie GJ, Lu Y, Liu BF, Xing DF, Han HJ, Yuan Z, Ren NQ (2020) Granular sludge coupling nitrate/nitrite dependent anaerobic methane oxidation with anammox: from proof-of-concept to high rate nitrogen removal. Environ Sci Technol 54(1):297-305

Fu L, Zhang F, Bai YN, Lu YZ, Ding J, Zhou D, Liu Y, Zeng RJ (2019) Mass transfer affects reactor performance, microbial morphology, and community succession in the methane-dependent denitrification and anaerobic ammonium oxidation co-culture. Sci Total Environ 651(1):291-297

Gambelli L, Guerrero-Cruz S, Mesman RJ, Cremers G, Jetten MSM, Op den Camp HJM, Kartal B, Lueke C, van Niftrik L (2018) Community composition and ultrastructure of a nitrate-dependent anaerobic methane-oxidizing enrichment culture. Appl Environ Microbiol 84(3):e02186-e02117

Guerrero-Cruz S, Cremers G, van Alen TA, Op den Camp HJM, Jetten MSM, Rasigraf O, Vaksmaa A (2018) Response of the anaerobic methanotroph "Candidatus Methanoperedens nitroreducens" to oxygen stress. Appl Environ Microbiol 84(24):e01832-e01818

Guerrero-Cruz S, Stultiens K, van Kessel MAHJ, Versantvoort W, Jetten MSM, Op den Camp HJM, Kartal B (2019) Key physiology of a nitrite-dependent methane-oxidizing enrichment culture. Appl Environ Microbiol 85:e0124-e00119

Harhangi HR, Le Roy M, van Alen T, Hu BL, Groen J, Kartal B, Tringe SG, Quan ZX, Jetten MSM, Op den Camp HJM (2012) Hydrazine synthase, a unique phylomarker with which to study the presence and biodiversity of anammox bacteria. Appl Environ Microbiol 78(3):752-758

Haroon MF, Hu S, Shi Y, Imelfort M, Keller J, Hugenholtz P, Yuan Z, Tyson GW (2013) Anaerobic oxidation of methane coupled to nitrate reduction in a novel archaeal lineage. Nature 500(7464):567570

Hauck M, Maalcke-Luesken FA, Jetten MSM, Huijbregts MAJ (2016) Removing nitrogen from wastewater with side stream anammox: what are the treat-offs between environmental impacts? Resour Conserv Recycl 107:212-219

Hu S, Zeng RJ, Burow LC, Lant P, Keller J, Yuan Z (2009) Enrichment of denitrifying anaerobic methane oxidizing microorganisms. Environ Microbiol Rep 1(5):377-384

Hu S, Zeng RJ, Haroon MF, Keller J, Lant PA, Tyson GW, Yuan Z (2015) A laboratory investigation of interactions between 
denitrifying anaerobic methane oxidation (DAMO) and anammox processes in anoxic environments. Sci Reports 5:8706

Hu Z, Wessels HJCT, van Alen TA, Jetten MSM, Kartal B (2019) Nitric oxide-dependent ammonium oxidation. Nat Commu 10:1244

Hug LA, Castelle CJ, Wrighton KC, Thomas BC, Sharon I, Frischkorn KR, Williams KH, Tringe SG, Banfield JF (2013) Community genomic analyses constrain the distribution of metabolic traits across the Chloroflexi phylum and indicate roles in sediment carbon cycling. Microbiome 1:22

in't Zandt MH, de Jong AE, Slomp CP, Jetten MSM (2018) The hunt for the most-wanted chemolitho-autotrophic spookmicrobes. FEMS Microbiol Ecol 94(6):fiy064

Kartal B, Kuenen JG, van Loosdrecht MCM (2010) Sewage treatment with anammox. Science 328(5979):702-703

Kartal B, Maalcke WJ, de Almeida NM, Cirpus I, Gloerich J, Geerts W, Op den Camp HJM, Harhangi HR, Janssen-Megens EM, Francoijs KJ, Stunnenberg HG, Keltjens JT, Jetten MSM, Strous M (2011) Molecular mechanism of anaerobic ammonium oxidation. Nature 479(7371):127-130

Kowalchuk GA, de Bruijn FJ, Head IM, Akkermans AD, van Elsas JD (2004) Molecular microbial ecology manual (MMEM), 2nd ed, vol 1. Kluwer Academic Publishing, London, United Kingdom

Lackner S, Bitter M, Vlaeminck SE, Joss A, Horn H, van Loosdrecht MCM (2014) Full-scale partial nitritation/anammox experiences an application survey. Water Res 55:292-303

Liu T, Hu S, Yuan Z, Guo J (2019) High-level nitrogen removal by simultaneous partial nitration, anammox and nitrite/nitratedependent anaerobic methane oxidation. Water Res 166:115057

Luesken FA, Sánchez J, van Alen TA, Sanabria J, Op den Camp HJM, Jetten MSM, Kartal B (2011a) Simultaneous nitrite-dependent anaerobic methane and ammonium oxidation processes. Appl Environ Microbiol 77:6802-6807

Luesken FA, van Alen TA, van der Biezen E, Frijters C, Toonen G, Kampman C, Hendrickx TL, Zeeman G, Temmink H, Strous M, Op den Camp HJM, Jetten MSM (2011b) Diversity and enrichment of nitrite-dependent anaerobic methane oxidizing bacteria from wastewater sludge. Appl Microbiol Biotechnol 92(4):845-854

Luesken FA, Zhu B, van Alen TA, Butler MK, Diaz MR, Song B, Op den Camp HJM, Jetten MSM, Ettwig KF (2011c) pmoA primers for detection of anaerobic methanotrophs. Appl Environ Microbiol 77(11):3877-3880

Luesken FA, Wu ML, Op den Camp HJM, Keltjens JT, Stunnenberg H, Francoijs KJ, Strous M, Jetten MSM (2012) Effect of oxygen on the anaerobic methanotroph 'Candidatus Methylomirabilis oxyfera': kinetic and transcriptional analysis. Environ Microbiol 14(4):1024 1034

Meng H, Wang YF, Chan HW, Wu RN, Gu JD (2016) Co-occurrence of nitrite-dependent anaerobic ammonium and methane oxidation processes in subtropical acidic forest soils. Appl Microbiol Biotechnol 100(17):7727-7739

Nie WB, Xie GJ, Ding J, Lu Y, Liu BF, Xing DF, Wang Q, Han HJ, Yuan $Z$, Ren NQ (2019) High performance nitrogen removal through integrating denitrifying anaerobic methane oxidation and anammox: from enrichment to application. Environ Int 132:105107

Nie WB, Xie GJ, Ding J, Peng L, Lu Y, Tan X, Yue H, Liu BF, Xing DF, Meng J, Han HJ, Ren NQ (2020) Operation strategies of n-DAMO and anammox process based on microbial interactions for high rate nitrogen removal from landfill leachate. Environ Int 139:105596

Parks DH, Imelfort M, Skennerton CT, Hugenholtz P, Tyson GW (2015) CheckM: assessing the quality of microbial genomes recovered from isolates, single cells, and metagenomes. Genome Res 25(7): 1043-1055

Raghoebarsing AA, Pol A, van de Pas-Schoonen KT, Smolders AJP, Ettwig KF, Rijpstra WIC, Schouten S, Damste JSS, Op den Camp HJM, Jetten MSM, Strous M (2006) A microbial consortium couples anaerobic methane oxidation to denitrification. Nature 440(7086):918-921

Rios-Del Toro EE, Valenzuela,EI, López-Lozano NG, Cortés-Martínez MG, Sánchez-Rodríguez MA, Calvario-Martínez O, SánchezCarrillo S, Cervantes FJ (2018a) Anaerobic ammonium oxidation linked to sulfate and ferric iron reduction fuels nitrogen loss in marine sediments. Biodegradation 29(5):429-442

Rios-Del Toro EE, Valenzuela EI, Ramírez JE, López-Lozano NE, Cervantes FJ (2018b) Anaerobic ammonium oxidation linked to microbial reduction of natural organic matter in marine sediments. Environ Sci Technol Lett 5(9):571-577

RStudio Team (2015) RStudio: integrated development environment for r. RStudio, Inc., Boston, MA Retrieved from http://www.rstudio. $\mathrm{com} /$

Rutherford K, Parkhill J, Crook J, Horsnell T, Rice P, Rajandream MA, Barrell B (2000) Artemis: sequence visualization and annotation. Bioinformatics 16(10):944-945

Schmid MC, Schmitz-Esser S, Jetten MSM, Wagner M (2001) 16S-23S rDNA intergenic spacer and 23S rDNA of anaerobic ammoniumoxidizing bacteria: implications for phylogeny and in situ detection. Environ Microbiol 3:450-459

Shen LD, Liu S, Huang Q, Lian X, He ZF, Geng S, Jin RC, He YF, Lou LP, Xu XY, Zheng P, Hu BL (2014) Evidence for the cooccurrence of nitrite-dependent anaerobic ammonium and methane oxidation processes in a flooded paddy field. Appl Environ Microbiol 80(24):7611-7619

Shi Y, Hu S, Lou J, Lu P, Keller J, Yuan Z (2013) Nitrogen removal from wastewater by coupling anammox and methane-dependent denitrification in a membrane biofilm reactor. Environ Sci Technol 47(20): $11577-11583$

Siniscalchi LA, Vale IC, Dell'Isola J, Chernicharo CA, Calabria Araujo J (2015) Enrichment and activity of methanotrophic microorganisms from municipal wastewater sludge. Environ Technol 36(9-12): $1563-1575$

Strous M, Jetten MSM (2004) Anaerobic oxidation of methane and ammonium. Annu Rev Microbiol 58:99-117

Strous M, Heijnen JJ, Kuenen JG, Jetten MSM (1998) The sequencing batch reactor as a powerful tool for the study of slowly growing anaerobic ammonium-oxidizing microorganisms. Appl Microbiol Biotechnol 50:589-596

Strous M, Fuerst JA, Kramer EHM, Logemann S, Muyzer G, van de PasSchoonen KT, Webb R, Kuenen JG, Jetten MSM (1999a) Missing lithotroph identified as new planctomycete. Nature 400:446-449

Strous M, Kuenen JG, Jetten MSM (1999b) Key physiology of anaerobic ammonium oxidation. Appl Environ Microbiol 65(7):3248-3250

Strous M, Pelletier E, Mangenot S, Rattei T, Lehner A, Taylor MW, Horn M, Daims H, Bartol-Mavel D, Wincker P, Barbe V, Fonknechten N, Vallenet D, Segurens B, Schenowitz-Truong C, Médigue C, Collingro A, Snel B, Dutilh BE, Op den Camp HJM, van der Drift C, Cirpus I, van de Pas-Schoonen KT, Harhangi HR, van Niftrik L, Schmid M, Keltjens JT, van de Vossenberg J, Kartal B, Meier H, Frishman D, Huynen MA, Mewes HW, Weissenbach J, Jetten MSM, Wagner M, Le Paslier D (2006) Deciphering the evolution and metabolism of an anammox bacterium from a community genome. Nature 440(7085):790-794

Stultiens K, Guerrero-Cruz S, van Kessel MAHJ, Jetten MSM, Kartal B, Op den Camp HJM (2019) Interactions between anaerobic ammonium- and methane-oxidizing microorganisms in a laboratory-scale sequencing batch reactor. Appl Microbiol Biotechnol 103:6783-6795

Vaksmaa A, Guerrero-Cruz S, van Alen TA, Cremers G, Ettwig KF, Lüke C, Jetten MSM (2017a) Enrichment of anaerobic nitratedependent methanotrophic 'Candidatus Methanoperedens nitroreducens' archaea from an Italian paddy field soil. Appl Microbiol Biotechnol 101(18):7075-7084 
Vaksmaa A, Jetten MS, Ettwig KF, Lüke C (2017b) McrA primers for the detection and quantification of the anaerobic archaeal methanotroph 'Candidatus Methanoperedens nitroreducens'. Appl Microbiol Biotechnol 101(4):1631-1641

van Kessel MAHJ, Stultiens K, Slegers MFW, Guerrero Cruz S, Jetten MSM, Kartal B, Op den Camp HJM (2018) Current perspectives on the application of $\mathrm{N}$-damo and anammox in wastewater treatment. Curr Opin Biotechnol 50:222-227

Versantvoort W, Guerrero-Cruz S, Speth DR, Frank J, Gambelli L, Cremers G, van Alen T, Jetten MSM, Kartal B, Op den Camp HJM, Reimann J (2018) Comparative genomics of 'Candidatus Methylomirabilis' species and description of ' $\mathrm{Ca}$. Methylomirabilis lanthanidiphila'. Front Microbiol 9:1672

Welte CU, Rasigraf O, Vaksmaa A, Versantvoort W, Arshad A, Op den Camp HJM, Jetten MSM, Lueke C, Reimann J (2016) Nitrate- and nitrite-dependent anaerobic oxidation of methane. Environ Microbiol Reports 8:941-956

Wiegand S, Jogler M, Boedeker C, Pinto D, Vollmers J, Rivas-Marín E, Kohn T, Peeters SH, Heuer A, Rast P, Oberbeckmann S, Bunk B, Jeske O, Meyerdierks A, Storesund JE, Kallscheuer N, Lücker S, Lage OM, Pohl T, Merkel BJ, Hornburger P, Müller R-W, Brümmer F, Labrenz M, Spormann AM, Op den Camp HJM, Overmann J, Amann R, Jetten MSM, Mascher T, Medema MH, Devos DP, Kaster A-K, Øvreås L, Rohde M, Galperin MY, Jogler C (2020) Cultivation and functional characterization of 79 Planctomycetes uncovers their unique biology. Nature Microbiol 5:126-140

Winkler MK, Ettwig KF, Vannecke TP, Stultiens K, Bogdan A, Kartal B, Volcke EI (2015) Modelling simultaneous anaerobic methane and ammonium removal in a granular sludge reactor. Water Res 73:323331
Xie GJ, Liu T, Cai C, Hu S, Yuan Z (2018) Achieving high-level nitrogen removal in mainstream by coupling anammox with denitrifying anaerobic methane oxidation in a membrane biofilm reactor. Water Res 131:196-204

Xu S, Lu W, Mustafa MF, Caicedo LM, Guo H, Fu X, Wang H (2017) Co-existence of anaerobic ammonium oxidation bacteria and denitrifying anaerobic methane oxidation bacteria in sewage sludge: community diversity and seasonal dynamics. Microb Ecol 74(4): $832-840$

Yamada T, Sekiguchi Y, Imachi H, Kamagata Y, Ohashi A, Harada H (2005) Diversity, localization, and physiological properties of filamentous microbes belonging to Chloroflexi subphylum I in mesophilic and thermophilic methanogenic sludge granules. Appl Environ Microbiol 71(11):7493-7503

Zhou J, Bruns MA, Tiedje JM (1996) DNA recovery from soils of diverse composition. Appl Environ Microbiol 62:316-322

Zhu B, van Dijk G, Fritz C, Smolders AJ, Pol A, Jetten MSM, Ettwig KF (2012) Anaerobic oxidization of methane in a minerotrophic peatland: enrichment of nitrite-dependent methane-oxidizing bacteria. Appl Environ Microbiol 78(24):8657-8665

Zhu B, Bradford L, Huang S, Szalay A, Leix C, Weissbach M, Táncsics A, Drewes JE, Lueders T (2017) Unexpected diversity and high abundance of putative nitric oxide dismutase (Nod) genes in contaminated aquifers and wastewater treatment systems. Appl Environ Microbiol 83(4):e02750-e02716

Publisher's note Springer Nature remains neutral with regard to jurisdictional claims in published maps and institutional affiliations. 